\title{
Updates on the Geology and Potential Petroleum System of the Bida Basin in Central Nigeria
}

\author{
Nuhu George Obaje $e^{1,3, *}$, Abdullahi Bomai ${ }^{2}$, Sunday Dabai Moses ${ }^{2}$, Mohammed Ali², \\ Abdulwahid Aweda ${ }^{3}$, Serah Japhet Habu ${ }^{4}$, Abdullahi Idris-Nda ${ }^{5}$, Aliyu Isah Goro ${ }^{5}$, Salome Waziri ${ }^{5}$ \\ ${ }^{1}$ Nigerian National Petroleum Corporation Chair in Basinal Studies, Ibrahim Badamasi Babangida University, Lapai, Nigeria \\ ${ }^{2}$ Frontier Exploration Services, Nigerian National Petroleum Corporation, Abuja, Nigeria \\ ${ }^{3}$ Department of Geology, Ibrahim Badamasi Babangida University, Lapai, Nigeria \\ ${ }^{4}$ National Remote Sensing Centre, Jos, Nigeria \\ ${ }^{5}$ Department of Geology, Federal University of Technology, Minna, Nigeria
}

Email address:

nobaje@yahoo.com (N. G. Obaje), nobaje@ibbu.edu.ng (N. G. Obaje)

${ }^{*}$ Corresponding author

\section{To cite this article:}

Nuhu George Obaje, Abdullahi Bomai, Sunday Dabai Moses, Mohammed Ali, Abdulwahid Aweda, Serah Japhet Habu, Abdullahi Idris-Nda, Aliyu Isah Goro, Salome Waziri. Updates on the Geology and Potential Petroleum System of the Bida Basin in Central Nigeria. Petroleum Science and Engineering. Vol. 4, No. 1, 2020, pp. 23-33. doi: 10.11648/j.pse.20200401.13

Received: February 12, 2020; Accepted: February 24, 2020; Published: March 10, 2020

\begin{abstract}
The Bida Basin is one of Nigeria's inland frontier basins. The conventional stratigraphy of the Bida Basin has the Bida Formation at the base in the northern sector, followed successively upward by the Sakpe, Enagi, and Batati Formations. In the southern sector, the Lokoja Formation is at the base, followed by the Patti Formation and ending with the Agbaja Formation at the top. Detailed field mapping carried out in this study has not identified the Batati Formation at the previously assigned Type Locality at Batati village. A new formational name of "Pattishabakolo Formation" has been proposed. The Patti Formation is also not mappable at the previously assigned Type Locality of the Mount Patti in Lokoja but mappable at Gegu, Ahoko and midway on the Agbaja Plateau. A new Type Locality at Ahoko has been proposed. Sediment thicknesses in the Bida Basin are shallower at the margin and generally deepen towards the centresuch that the central portions constitute the most prospective areas. Geophysical aeromagnetic interpretation has assisted in the interpretation of the geology of the basin. Organic geochemical studies show that the Kudu Shale in the Northern Bida Basin equivalent to the Ahoko Shale in the Southern Bida Basin constitutes the source rocks in the potential petroleum system. With averages for source rock thickness of $40 \mathrm{~m}$, area of basin of $45,000 \mathrm{~km}^{2}$, TOC of $9.0 \mathrm{wt} \%$, and HI of $220 \mathrm{mgHC} / \mathrm{gTOC}$, charge modeling indicates $623 \mathrm{million}$ barrels of oil equivalent extractable hydrocarbons in the Bida Basin, at current knowledge and if the appropriate maturity has been attained at deeper sections. The Bida/Lokoja Formation sandstones as well as the well sorted sandstones in the Enagi Formation constitute potential reservoirs in the basin. Regional seals are provided by the clayey members of the Enagi and Batati Formations. Potential traps are both structural and stratigraphical.
\end{abstract}

Keywords: Frontier Basins, Bida Basin, Kudu Shale, Hydrocarbons, Petroleum System

\section{Introduction}

The Bida Basin (Figure 1) is one of Nigeria's inlandfrontier sedimentary basins that are tectonically and paleogeographically related to the series of Cretaceous and later rift basins in Central and West Africa whose origin is attributed to the opening of the South Atlantic (Figure 2). Interpretations of Landsat imageries and geophysical data have suggested that the Bida Basin is bounded by a system of linear faults trending NW-SE with central positive gravimetric anomalies flanked by negative anomalies, similar to the adjacent Benue Trough and typical of rift structures [1, 2]. The structural characteristics and tectonic evolution of the Sokoto Basin are still being studied. Commercial hydrocarbon accumulations have been discovered in several basins within this rift structure (Figure 2). In SW Chad, 
development of the Doba discovery (with estimated reserves of about 1 billion barrels) resulted in the construction of a $1070 \mathrm{~km}$ long pipeline to the Atlantic coast. In the Sudan, "giant" fields (including Unity 1 and 2, Kaikang and Heglig) have been discovered in the Muglad Basin [3].

The Bida Basin trends NW-SE extending from Kontagora in the north to the area slightly beyond Lokoja in the south (Figure 1). It is delimited in the NE and SW by the basement complex and merges with the Anambra and Sokoto Basins to the SE and
NW respectively. Its sedimentary fill comprises post-orogenic molasse and thin unfolded marginal marine sediments. The basin is a gently down-warped trough whose origin is closely connected with Santonian orogenic movements in SE Nigeria and the Benue valley. The basin also trends perpendicular to the main axis of the Benue Trough and the Niger Delta Basin and is regarded as the NW extension of the Anambra Basin, both of which were major depocentres during the third major transgressive cycle in the Late Cretaceous.

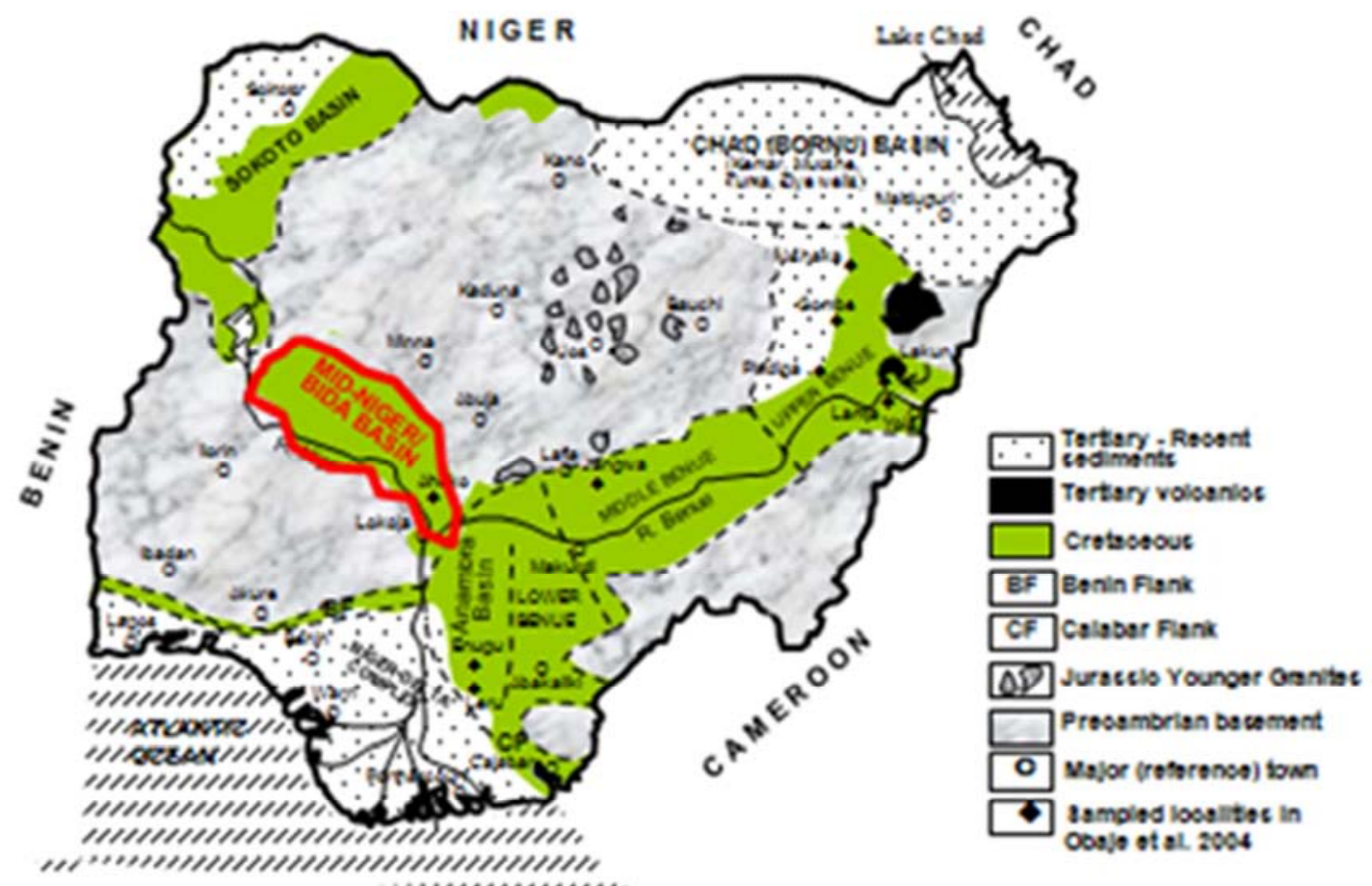

Figure 1. Generalized geological map of Nigeria showing the location of the Bida Basin (modified from [4)).

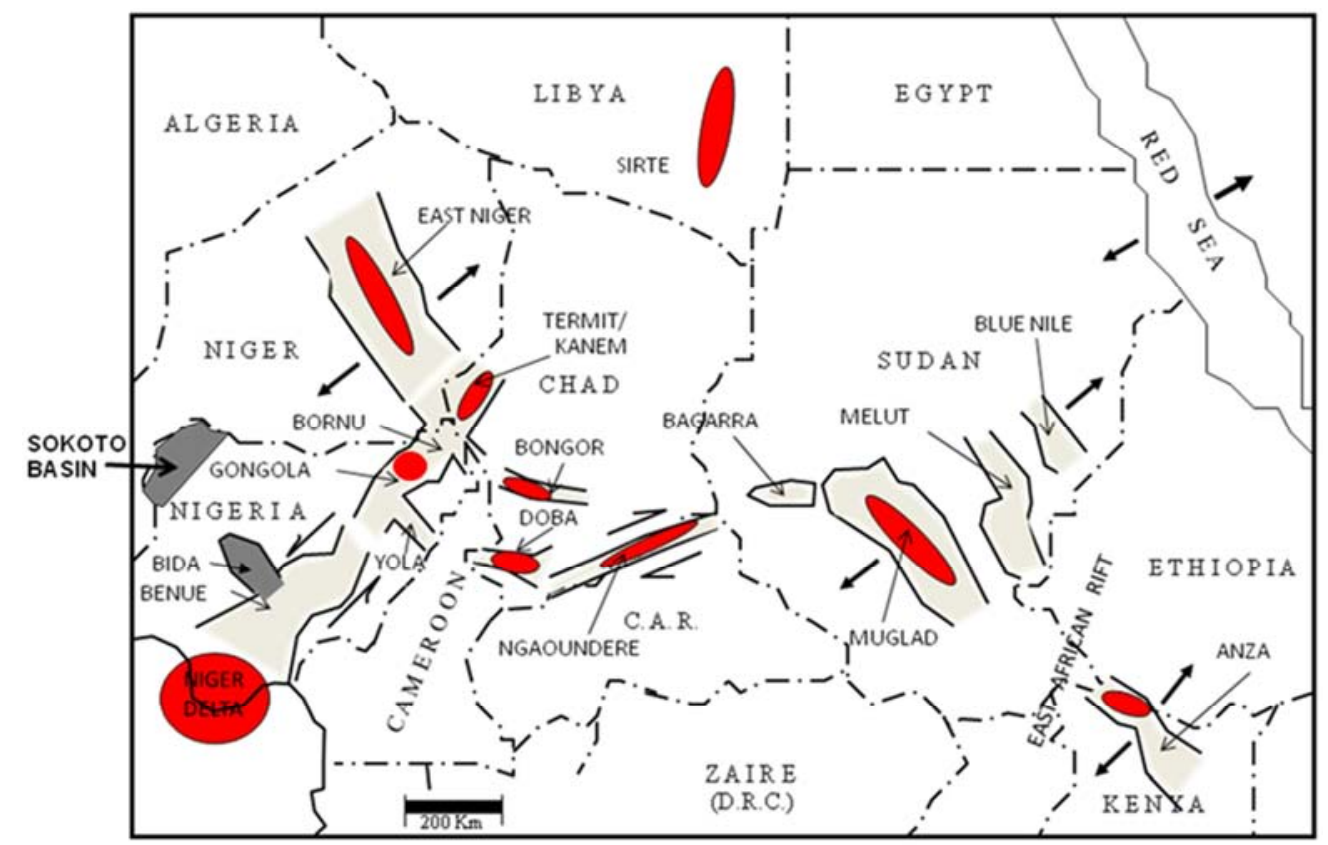

Figure 2. The Bida Basin is a part of the western, central and eastern African rifted basins system. Hydrocarbon deposits have been discovered in commercial quantities within many of the basins within the system. 


\section{Stratigraphy}

Previous workers on the Bida Basin subdivided the basin into two portions $[5,6]$, namely the Northern Bida Basin and the Southern Bida Basin. No concrete line of subdivision can be drawn but the boundary approximates the subdivision shown in Figure 3. The authors also identified four mappable lithostratigraphic units in the Northern Bida Basin, namely, the Bida Sandstone (divided into the Doko Member and the Jima Member), the Sakpe Ironstone, the Enagi Siltstone, and the Batati Formation. Stratigraphic units in the Bida Basin, the Anambra Basin and the Sokoto Basin are genetically related (Figures 4, 5).

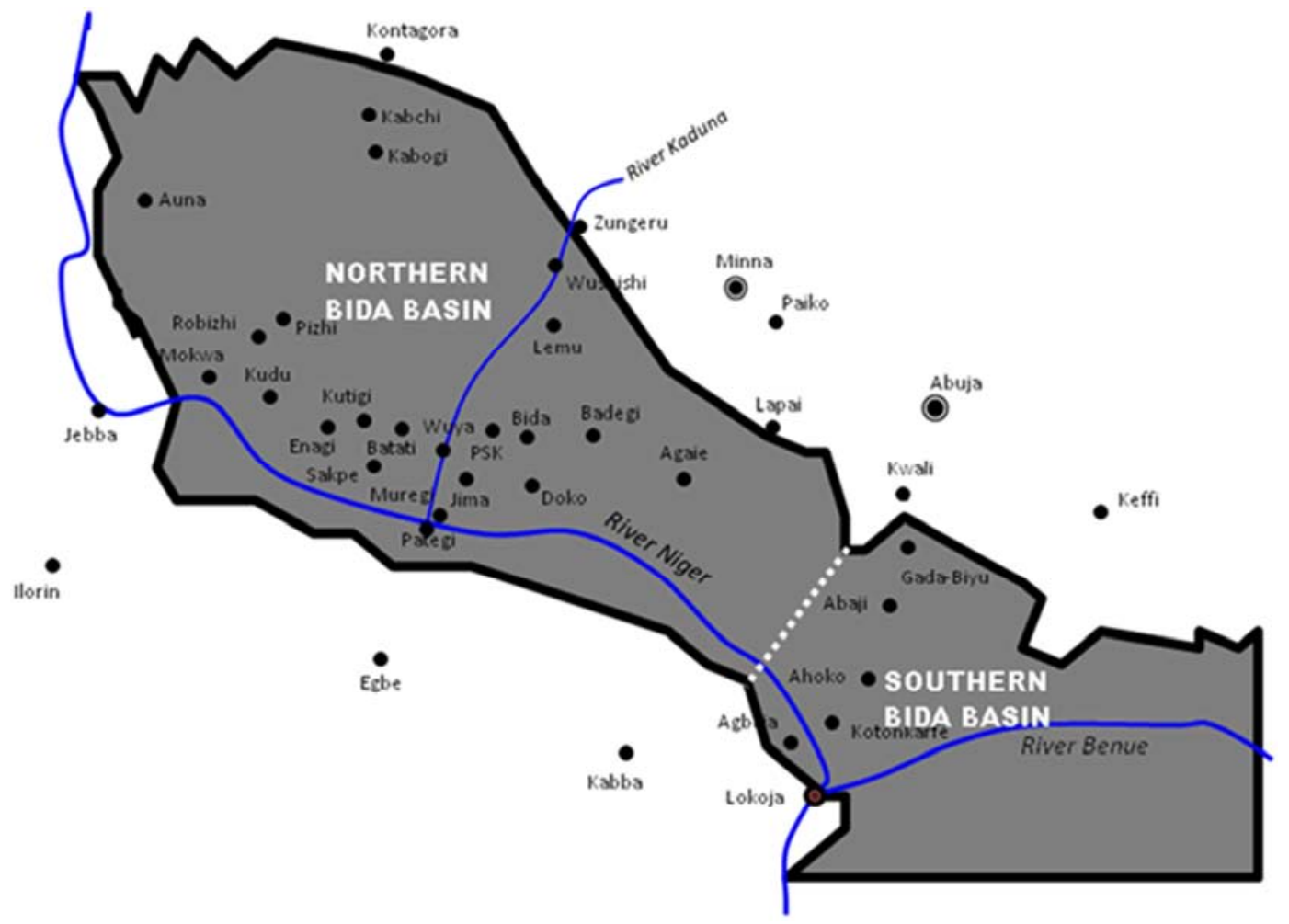

Figure 3. Outline of the Bida Basin in Central Nigeria indicating the boundary between the northern and southern sectors [4, 5].

In the Southern Bida Basin (which has been studied in more detail [e.g. 7, 8], exposures of sandstones and conglomerates of the Lokoja Formation directly overly the Pre-Cambrian to Lower Paleozoic basement gneisses and schists. This is overlain by the alternating shales, siltstones, claystones and sandstones of the Patti Formation (ca. 70-100 m thick in the
Koton-Karfi and Abaji axis). The Patti Formation is succeeded by the claystones, concretionary siltstones and ironstones of the Agbaja Formation. The Type Localities are supposedly the names used respectively for the geological formations.

Further reviews on the Bida Basin are available in [9], amongst others.

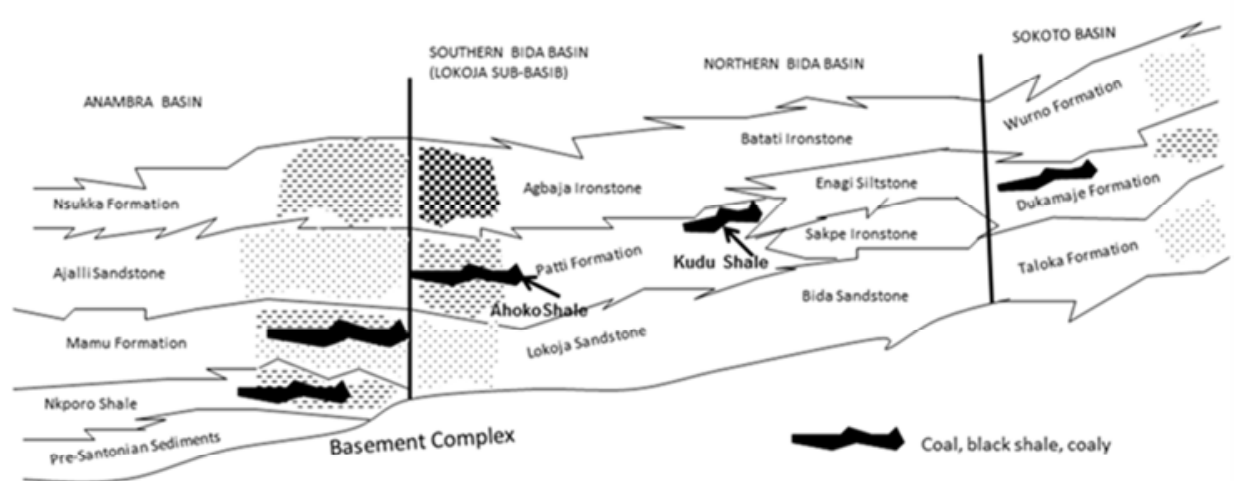

Figure 4. Stratigraphy of Campanian-Maastrichtian formations in the Bida Basin correlated to the Anambra Basin and the Sokoto Basin. 
SE

NW

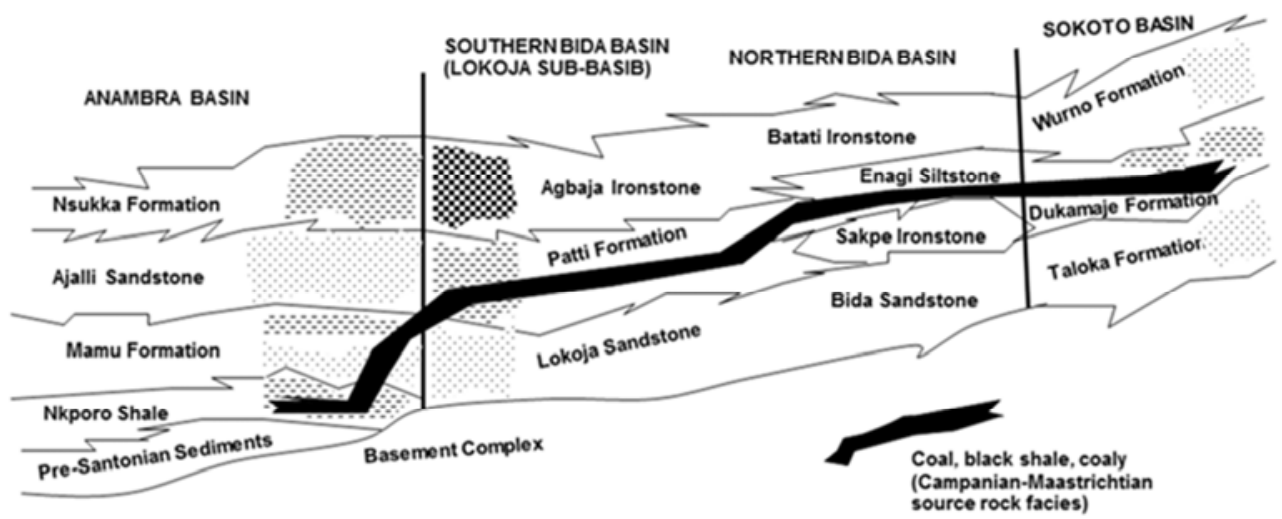

Figure 5. The source rock development (coal, black shales, coaly shale) is a continuous linear belt from the Anambra Basin (Enugu/Nkporo Shale, Mamu Fm) in the south through the Bida Basin (Ahoko/Kudu Shale) in the middle to the Sokoto Basin (Dukamaje Fm) in the north.

\section{Geology}

A traverse through the Bida Basin to map and log exposed sections and to identify formational units by $[5,6]$ (Figures 6-11) resulted in the construction of the updated geological map of the basin shown in Figure 12. Generally, the Bida/Lokoja Formations made up dominantly of poorly sorted, ripple marked, bioturbated sandstone occupy the outer flanks of the basin and have the shallowest depth to basement. This formation occupies roughly $40 \%$ of the surface area of the Bida Basin. The Sakpe Formation (concretionary ironstones and highly feruginized sandstone) and the Batati Formation (pisolitic ironstone in clayey groundmass) occupy roughly $10 \%$ of the surface area while the Enagi/Patti Formation (siltstones, shales and minor sandstones) occupy approximately $50 \%$ of the mapped area and are widespread at the centre of the basin. The carbonaceous/dark coloured shales of the Kudu Member and
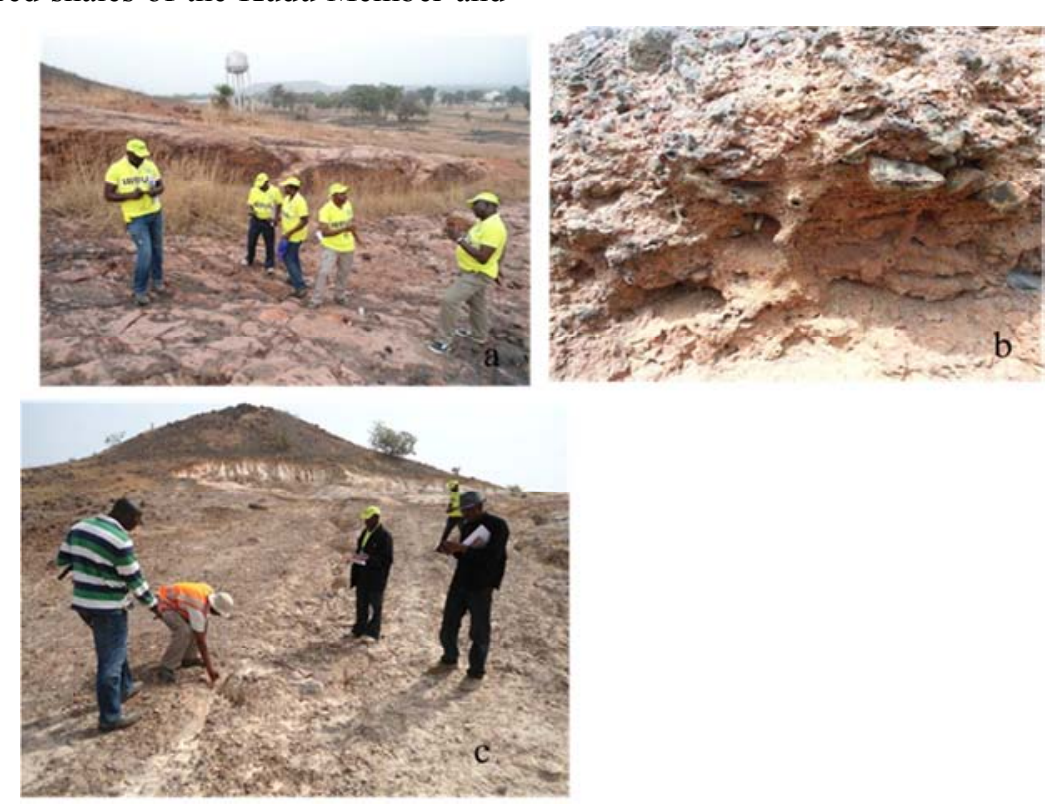

Figure 6. Geological mapping in the Bida Basin Bida Sandstone (Doko Member) at Doko village; (b) Bida Sandstone (Jima Member) at Jima village; (c) Enagi Formation (largely siltstone) at the Enagi village.
Ahoko Member are encased in the Enagi and Patti Formation respectively. The Bida Basin generally deepens towards the centre of the basin (Figures 13, 14). However, geological cross-sections show interpretations reminiscence of horst and graben structures showing areas like Pattishabakolo near Bida and Kandi near Gulu as sitting on grabens. These areas are the deepest portions of the Bida Basin and hence geologically most prospective.

\section{Aeromagnetic Geophysics}

The results of the aeromagnetic processing and interpretations have assisted to refine and redefine the earlier geologically postulated prospective areas. The interpreted aeromagnetic map corroborates the central portions of the Bida Basin to be deepest with some sub-basins around Pattishabakolo, Gegu and Agbaja areas (Figure 15). 


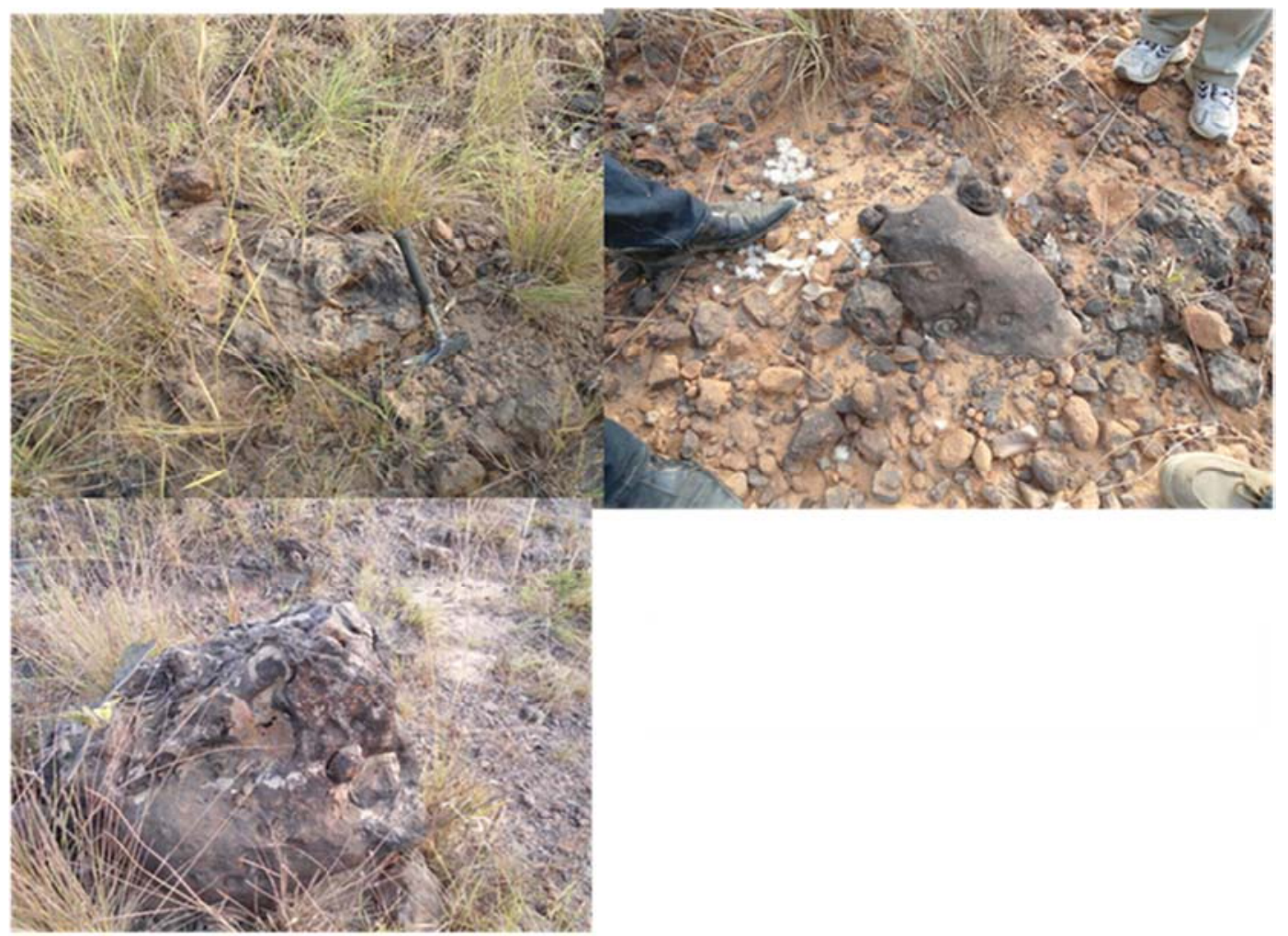

Figure 7. Variable concretionary ironstone forms of the Sakpe Formation at Sakpe village.
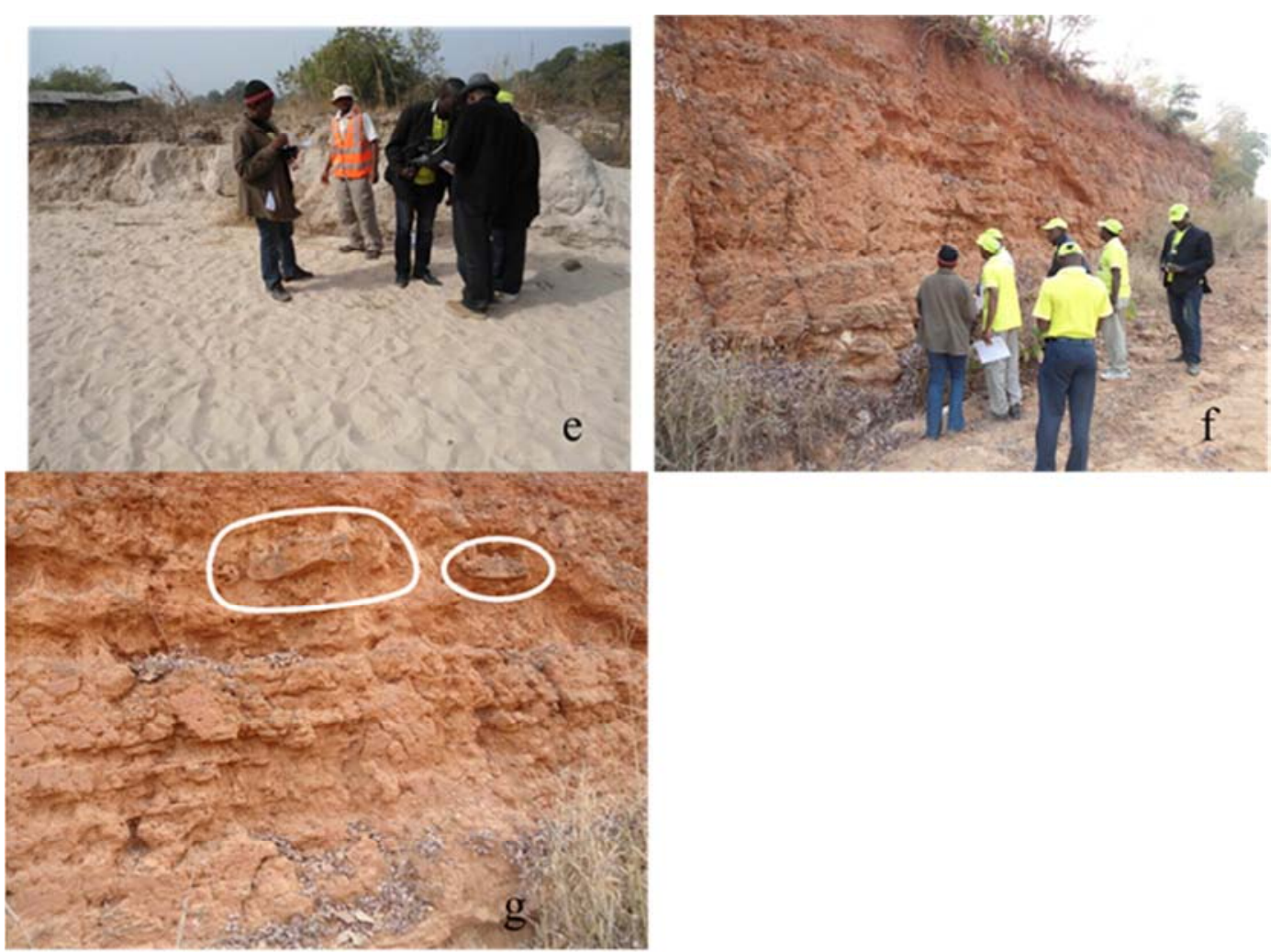

Figure 8. Geological mapping in the Bida Basin; (e) Loose sands of the Enagi Formation at the village of Batati on the Bida-Mokwa road; (f, g) Concretionary ellipsoidal ironstone in clayey groundmass of Batati Formation at Pattishabakolo near Bida. 

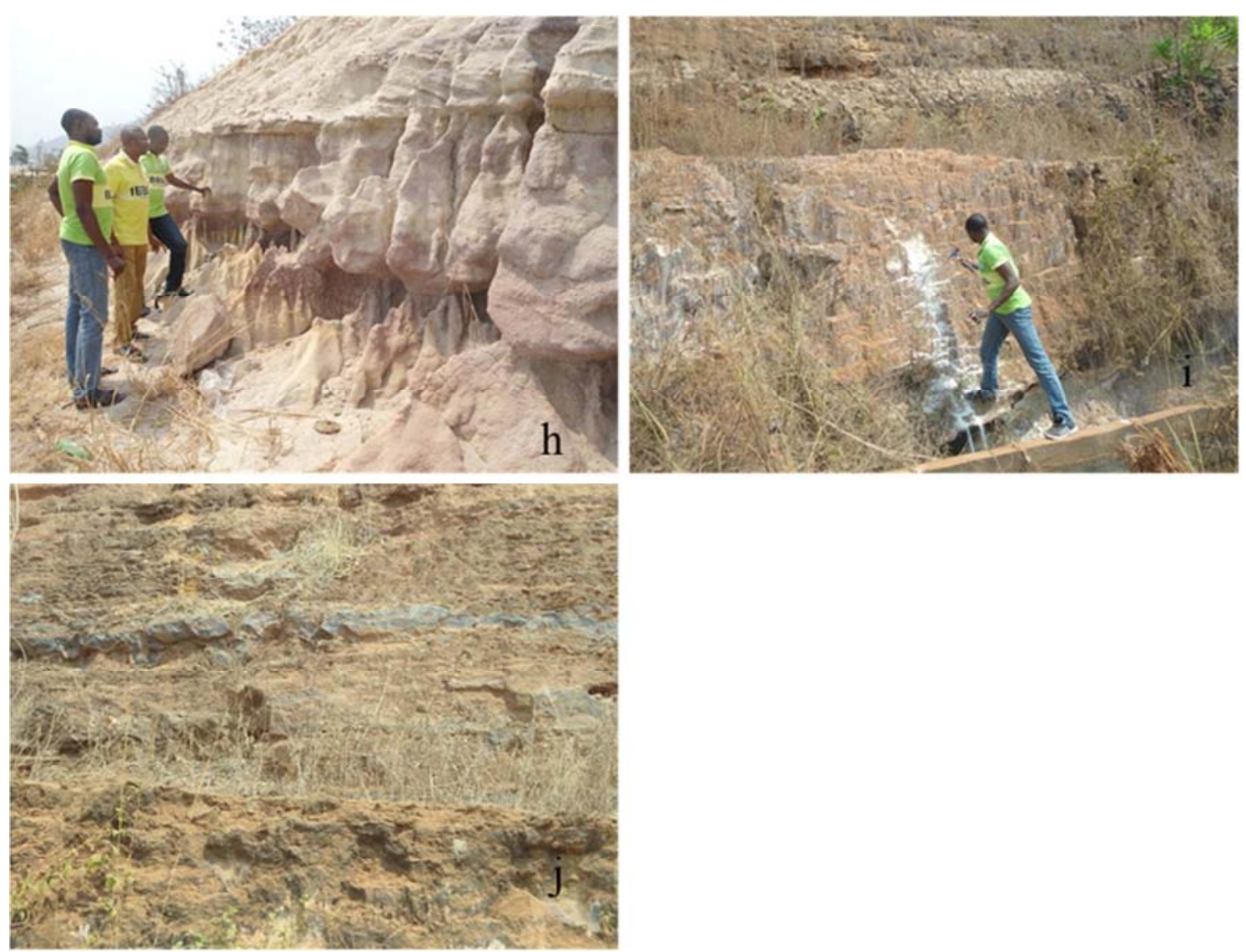

Figure 9. Geological mapping in the Bida Basin; (h) Poorly sorted gritty sandstones of the Lokoja Formation at NATACO station in Lokoja Well sorted medium to fine grained sandstones of the Patti Formation midway on the AgbajaPlateau; (j) Ironstone bands running through the Agbaja Formation at the top of the Agbaja Plateau.

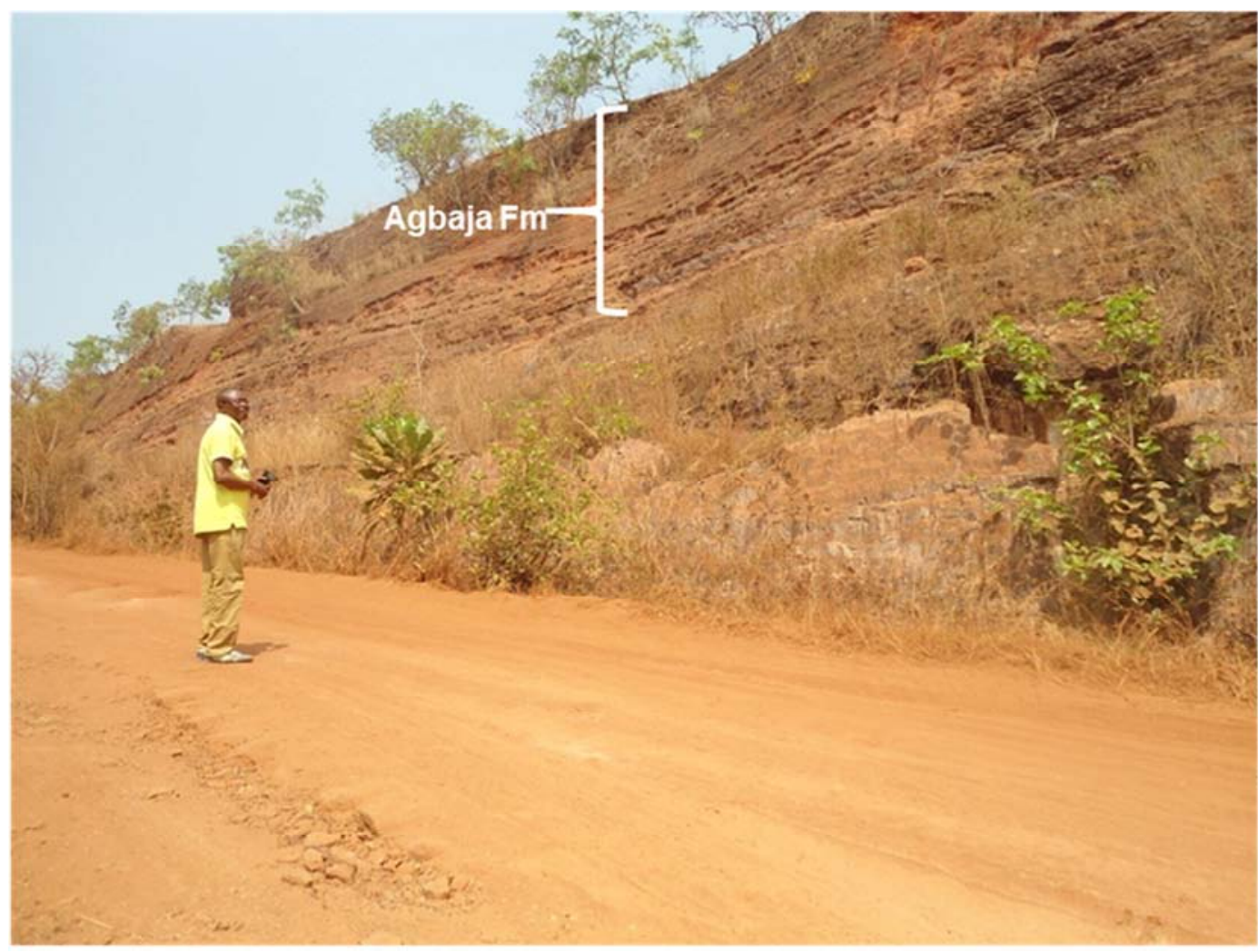

Figure 10. The Agbaja Formation at the top of the Agbaja Plateau on the entrance to Agbaja village near Lokoja. 

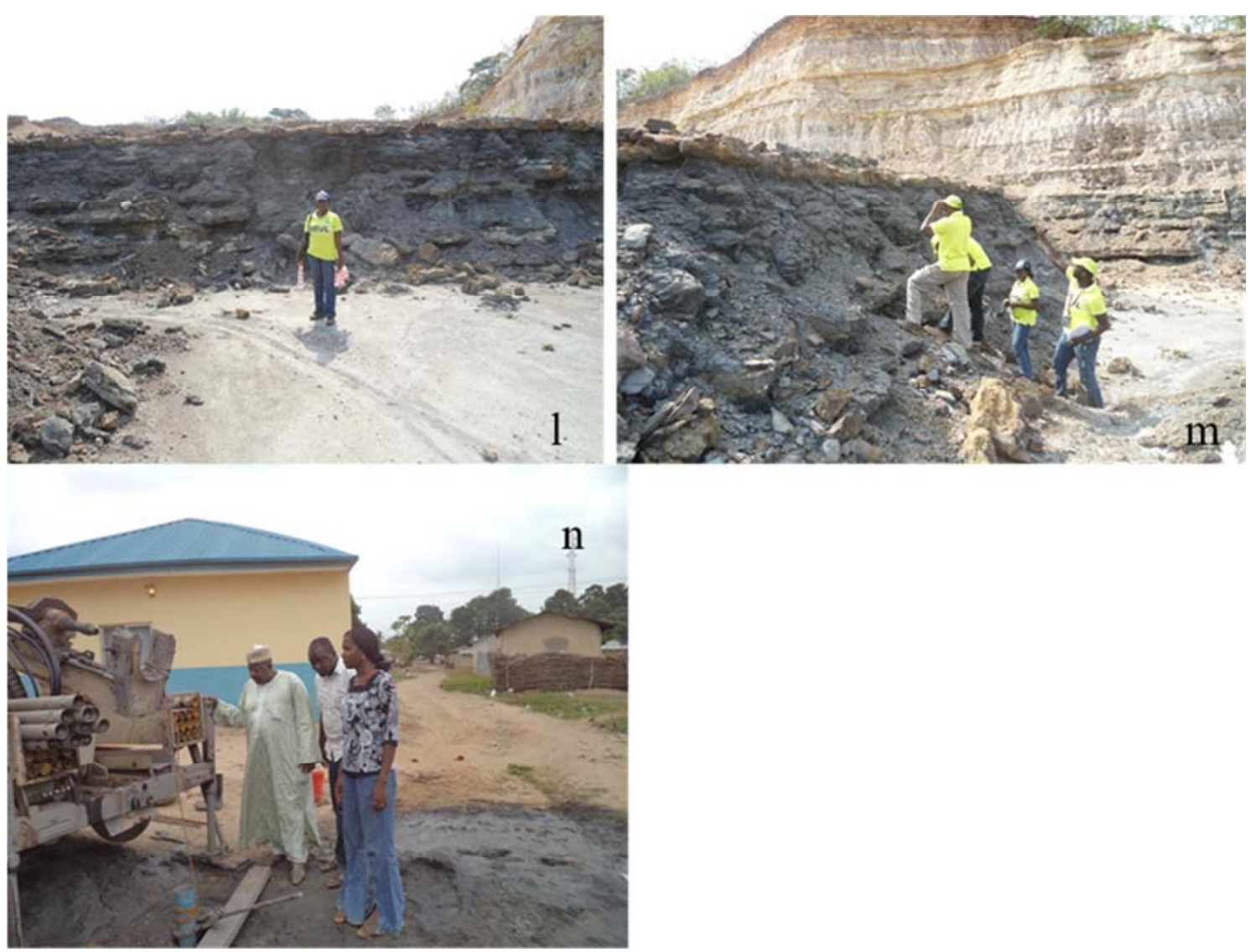

Figure 11. Geological mapping in the Bida Basin; $(l, m)$ Dark carbonaceous shales of the Ahoko Shale Member at the village of Ahoko on the Lokoja-Abuja Expressway; (n) Drilling to reach the Kudu Shale Member within the Enagi Formation at the village of Kudu on the Bida-Mokwa road.

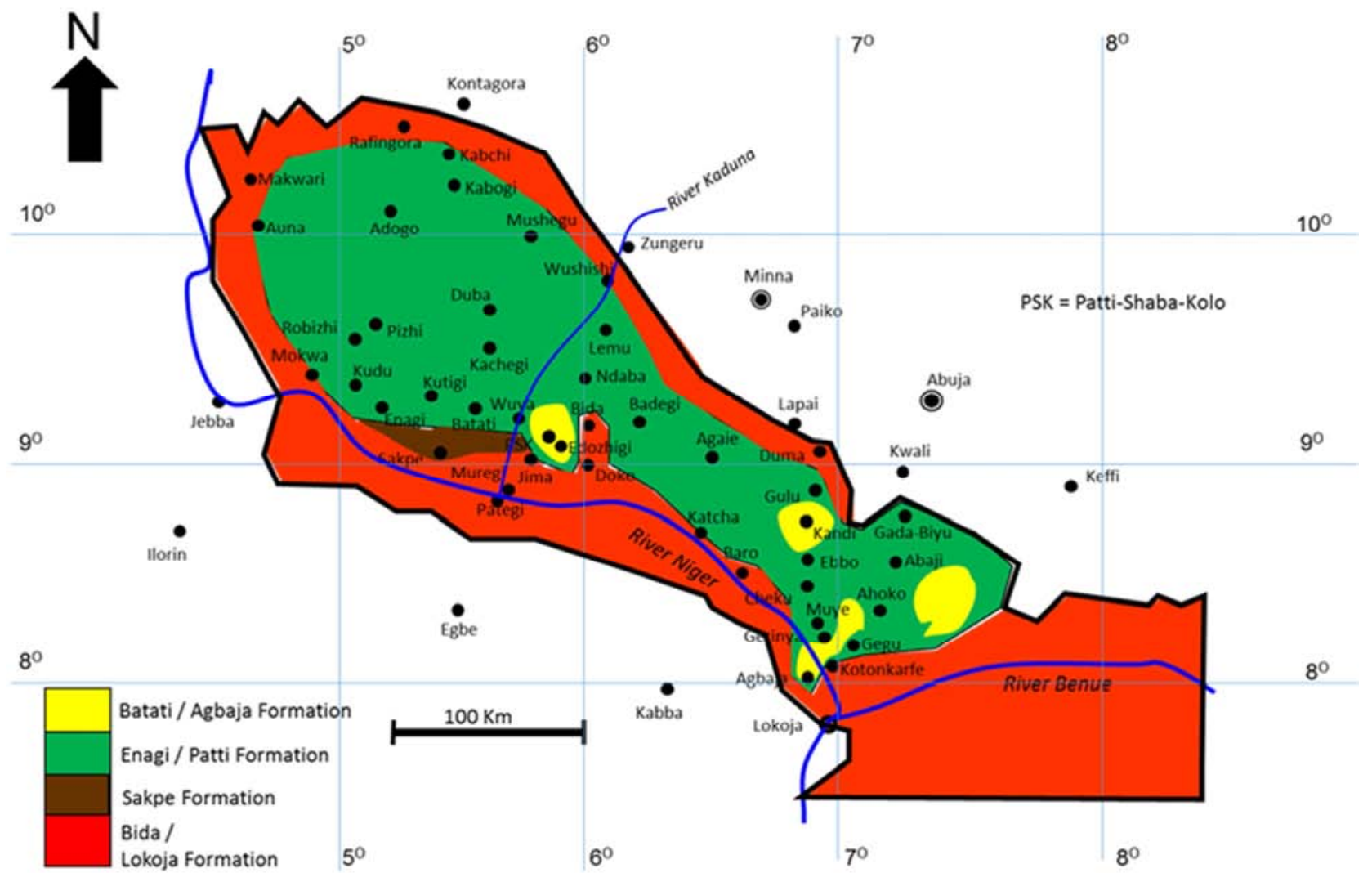

Figure 12. Upated geological map of the Bida Basin. 


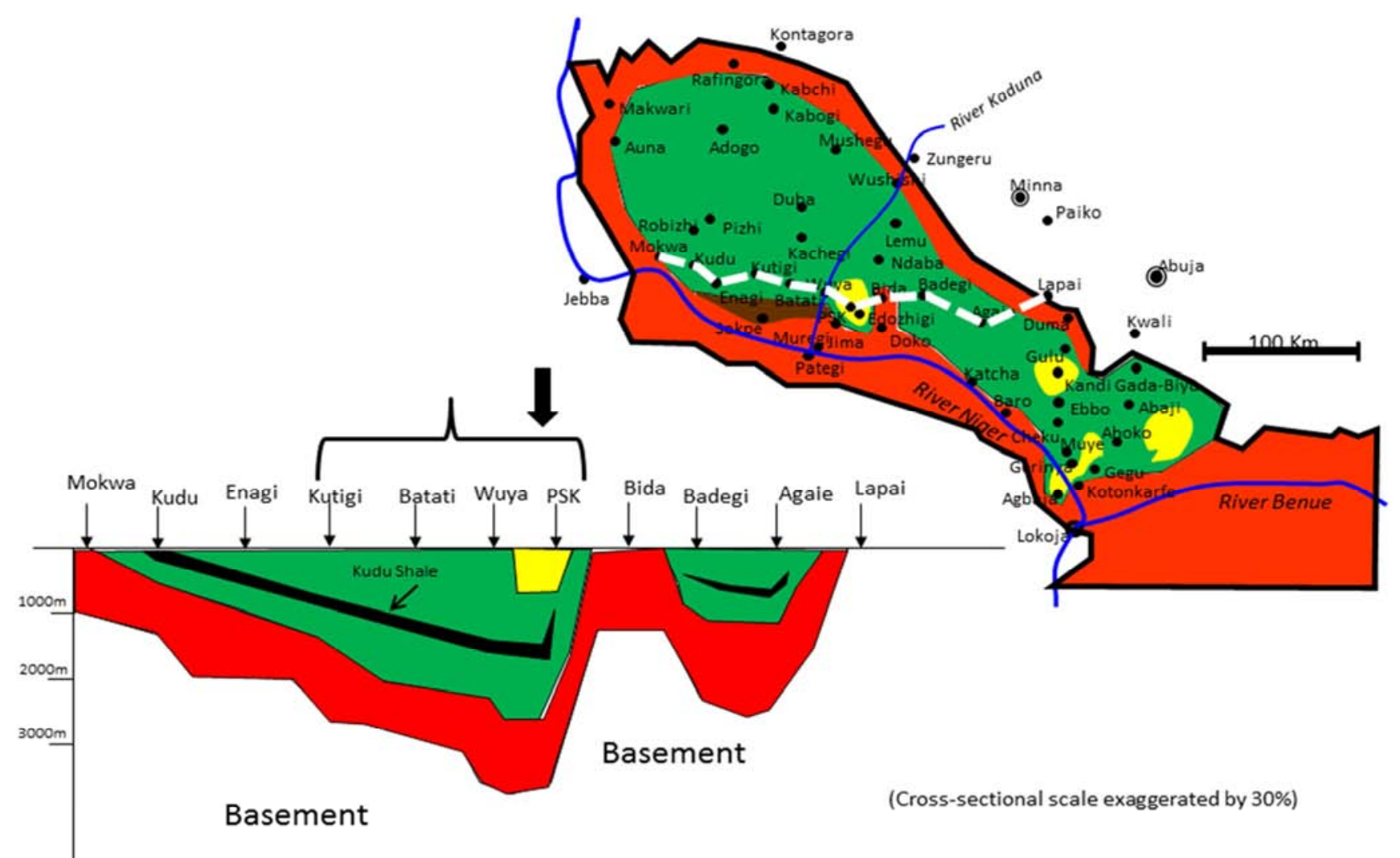

Figure 13. Cross section Mokwa-Lapai showing possible thickest pile at Pattishabakolo Aeromagnetic and seismic data interpretation may result in a different scenario.

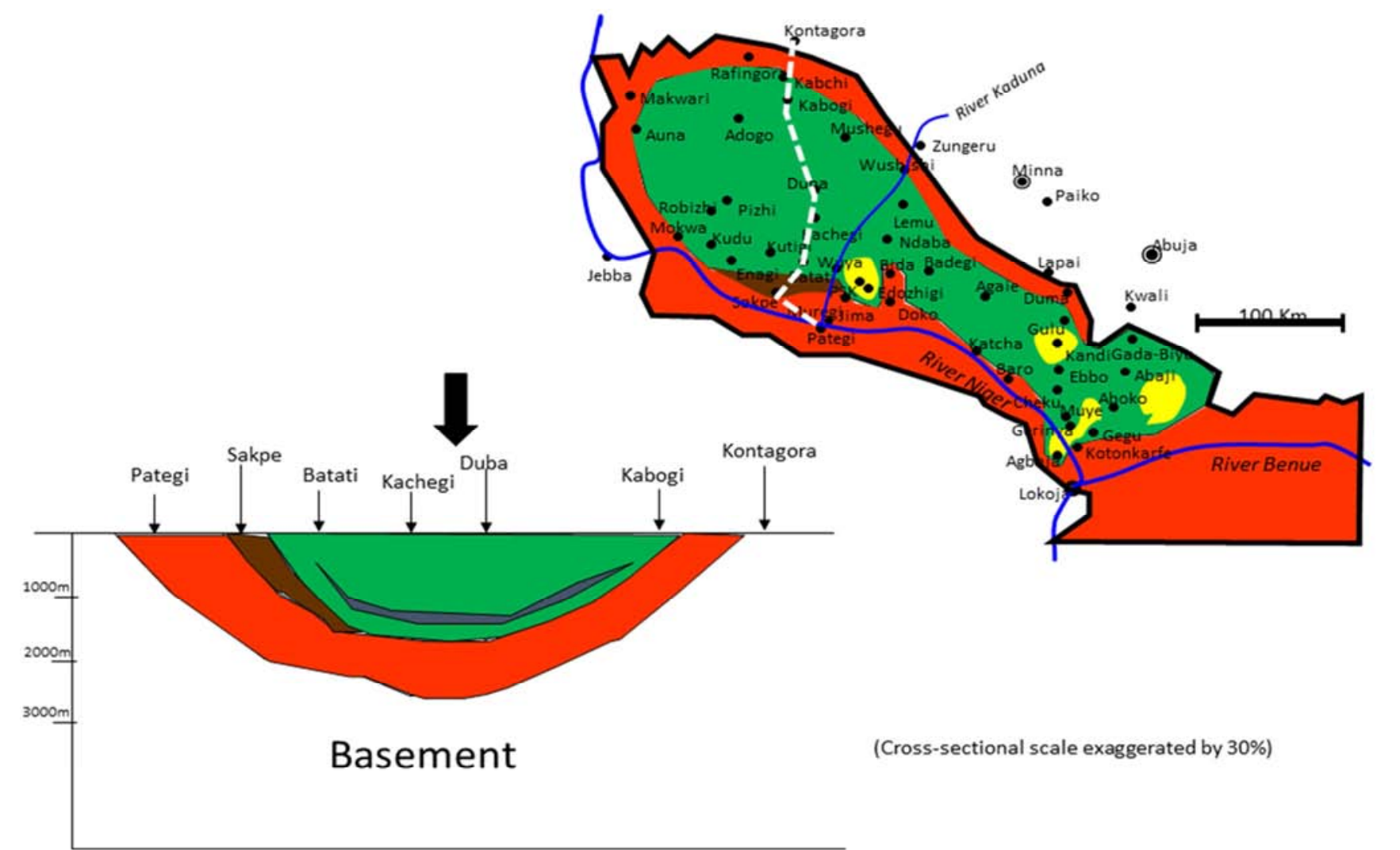

Figure 14. Cross section Pategi-Mokwa showing that the Bida Basin generally deepens towards the centre of the basin. Aeromagnetic and seismic data interpretation may result in a different scenario. 


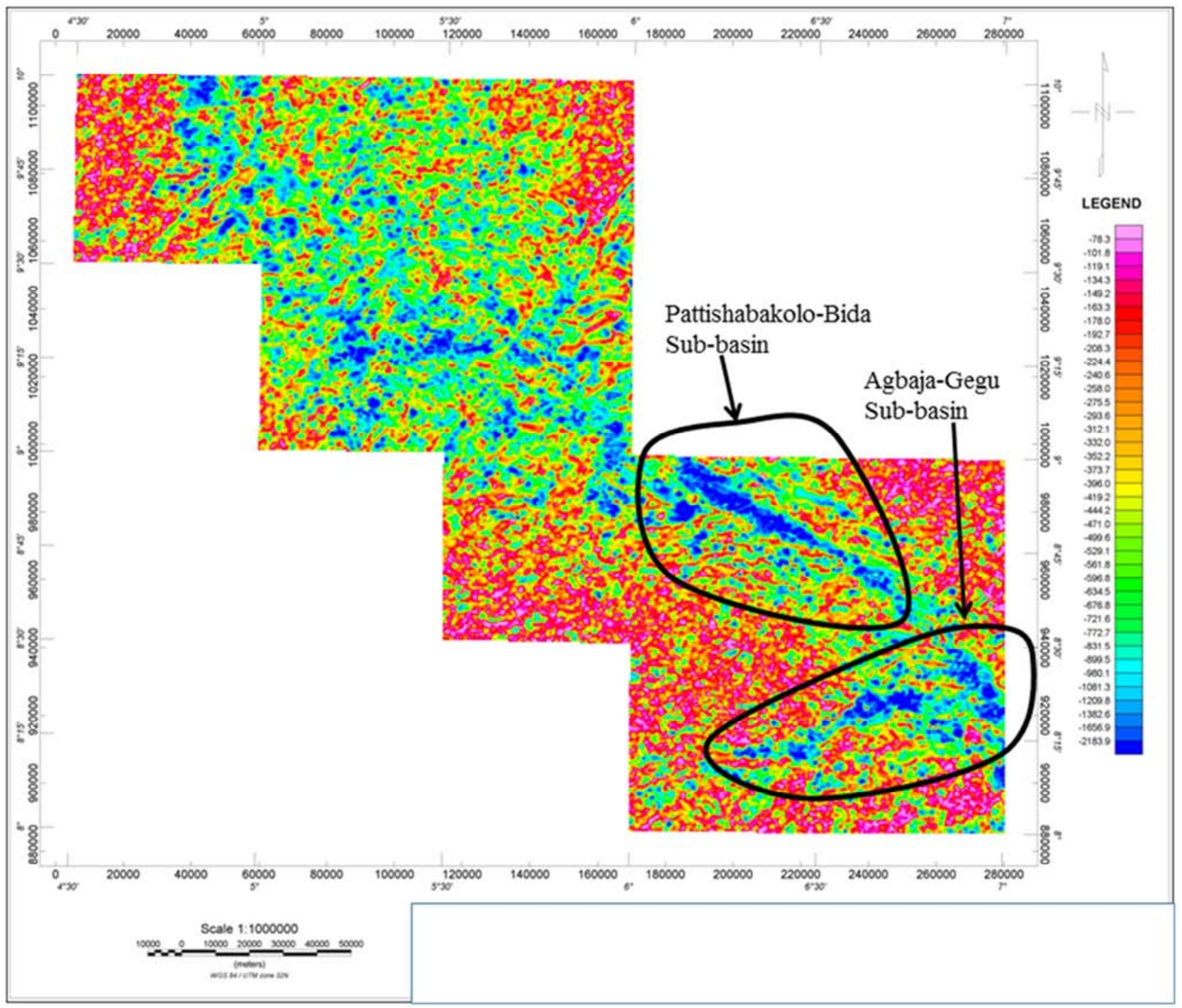

Figure 15. Interpreted aeromagnetic map of the Bida Basin showing that deepest portions are around Pattishabakolo and Agbaja-Gegu areas.

\section{Geochemistry and Charge Modeling}

Table 1 as presented earlier by [5] shows the Rock-Eval pyrolysis results of some representative samples obtained from shallow wells drilled in Agaie and Kudu within the Northern Bida Basin and from outcrop sections at Ahoko in the Southern Bida Basin. Eighty five percent (85\%) of the samples have TOC values of more than $0.5 \mathrm{wt} \%$, the minimum limit required for hydrocarbon generation. All samples from the Agaie well (Enagi Formation, sandy units) have no potential to generate hydrocarbons. The Kudu Shale, which is expected to be the major source rock in the Northern Bida Basin, lies probably still deeper down than the $70 \mathrm{~m}$ depth penetrated by the Agaie well.

Juxtaposition of the HI against the Tmax (thermal maturity) (Figure 16) shows that the source rocks in the Bida
Basin are below the entrant of the oil window (slightly immature to early mature). The diagram, however, represents results on samples obtained at the surface to maximum $70 \mathrm{~m}$ depth. It is expected that at depths where oil generation and entrapment would take place $(2000-4000 \mathrm{~m})$, the source rocks would have entered the oil window, whereby majority would be in the gas and oil and gas zones.

With averages for source rock thickness of $40 \mathrm{~m}$, area of basin of $45,000 \mathrm{~km}^{2}$, TOC of $9.0 \mathrm{wt} \%$, and HI of $220 \mathrm{mgHC} / \mathrm{gTOC}$ for a another well drilled at Makera on proprietary basis, charge modeling indicates 623 million barrels of oil equivalent extractable hydrocarbons in the Bida Basin, if the appropriate maturity has been attained at deeper sections and if other petroleum system requirements are available (good quality reservoir, traps, etc). 
Table 1. Rock Eval pyrolysis results of some selected samples from the Bida Basin [5].

\begin{tabular}{|c|c|c|c|c|c|c|c|c|c|c|c|}
\hline \multirow{2}{*}{ Client ID } & \multirow{2}{*}{ Sample Type } & \multirow{2}{*}{ Leco TOC } & \multicolumn{3}{|l|}{ RE } & \multirow{2}{*}{$\operatorname{Tmax}\left({ }^{\circ} \mathrm{C}\right)$} & \multirow{2}{*}{ HI } & \multirow{2}{*}{ OI } & \multirow{2}{*}{$\mathbf{S 2} / \mathbf{S 3}$} & \multirow{2}{*}{ S1/TOC*100 } & \multirow{2}{*}{ PI } \\
\hline & & & S1 & S2 & S3 & & & & & & \\
\hline Agaie 30 & Well & 0.08 & 0.05 & 0.08 & 0.28 & 403 & 96 & 337 & 0.3 & 60 & 0.38 \\
\hline Agaie 38 & Well & 0.07 & 0.06 & 0.11 & 0.24 & 342 & 149 & 324 & 0.5 & 81 & 0.35 \\
\hline Agaie 40 & Well & 0.07 & 0.03 & 0.09 & 0.44 & 404 & 138 & 677 & 0.2 & 46 & 0.25 \\
\hline Ahoko 11 (C) & Outcrop & 1.84 & 0.04 & 0.76 & 1.00 & 419 & 41 & 54 & 0.8 & 2 & 0.05 \\
\hline Ahoko 13 (A) & Outcrop & 1.90 & 0.05 & 0.48 & 1.28 & 416 & 25 & 67 & 0.4 & 3 & 0.09 \\
\hline Ahoko 17 (A) & Outcrop & 2.40 & 0.06 & 1.83 & 1.23 & 423 & 76 & 51 & 1.5 & 2 & 0.03 \\
\hline Ahoko 19 (B) & Outcrop & 2.56 & 0.08 & 2.10 & 1.02 & 425 & 82 & 40 & 2.1 & 3 & 0.04 \\
\hline Ahoko 1 (A) & Outcrop & 0.70 & 0.03 & 0.29 & 0.24 & 418 & 41 & 34 & 1.2 & 4 & 0.09 \\
\hline Ahoko 3 (B) & Outcrop & 1.60 & 0.05 & 0.85 & 0.88 & 418 & 53 & 55 & 1.0 & 3 & 0.06 \\
\hline Ahoko 9 (D) & Outcrop & 1.23 & 0.04 & 0.37 & 0.39 & 416 & 30 & 32 & 0.9 & 3 & 0.10 \\
\hline Kudu 30 & Well & 2.41 & 0.12 & 3.78 & 0.82 & 424 & 157 & 34 & 4.6 & 5 & 0.03 \\
\hline Kudu 36 & Well & 54.19 & 0.52 & 77.24 & 8.64 & 386 & 143 & 16 & 8.9 & 1 & 0.01 \\
\hline Kudu 38 & Well & 1.45 & 0.08 & 2.41 & 0.53 & 425 & 167 & 37 & 4.5 & 6 & 0.03 \\
\hline Kudu 51 & Well & 4.62 & 0.24 & 18.59 & 1.10 & 430 & 402 & 24 & 16.9 & 5 & 0.01 \\
\hline Kudu 53 & Well & 38.09 & 1.54 & 102.17 & 6.60 & 413 & 268 & 17 & 15.5 & 4 & 0.01 \\
\hline Kudu 54 & Well & 21.28 & 0.77 & 57.07 & 4.81 & 418 & 268 & 23 & 11.9 & 4 & 0.01 \\
\hline Kudu 56 & Well & 12.84 & 0.49 & 32.61 & 3.17 & 422 & 254 & 25 & 10.3 & 4 & 0.01 \\
\hline Kudu 60 & Well & 1.82 & 0.11 & 3.56 & 0.46 & 422 & 195 & 25 & 7.7 & 6 & 0.03 \\
\hline Kudu 65 & Well & 0.67 & 0.05 & 0.72 & 0.34 & 427 & 108 & 51 & 2.1 & 7 & 0.06 \\
\hline Kudu 71 & Well & 0.73 & 0.07 & 1.54 & 0.57 & 429 & 212 & 79 & 2.7 & 10 & 0.04 \\
\hline
\end{tabular}

TOC $=$ Total Organic Carbon, wt.\%.

$\mathrm{S} 1=$ Volatile hydrocarbon $(\mathrm{HC})$ content, $\mathrm{mg} \mathrm{HC} / \mathrm{g}$ rock.

$\mathrm{S} 2=$ Remaining $\mathrm{HC}$ generative potential, $\mathrm{mg} \mathrm{HC} / \mathrm{g}$ rock.

$\mathrm{S} 3=$ Carbon dioxide content, $\mathrm{mg} \mathrm{CO} 2 / \mathrm{g}$ rock.

$\mathrm{HI}=$ Hydrogen index $=\mathrm{S} 2 \times 100 / \mathrm{TOC}, \mathrm{mg} \mathrm{HC} / \mathrm{gTOC}$.

$\mathrm{OI}=$ Oxygen Index $=\mathrm{S} 3 \times \mathrm{x}$ 100/TOC, $\mathrm{mg} \mathrm{CO} 2 / \mathrm{gTOC}$.

$\mathrm{PI}=$ Production Index $=\mathrm{S} 1 /(\mathrm{S} 1+\mathrm{S} 2)$.

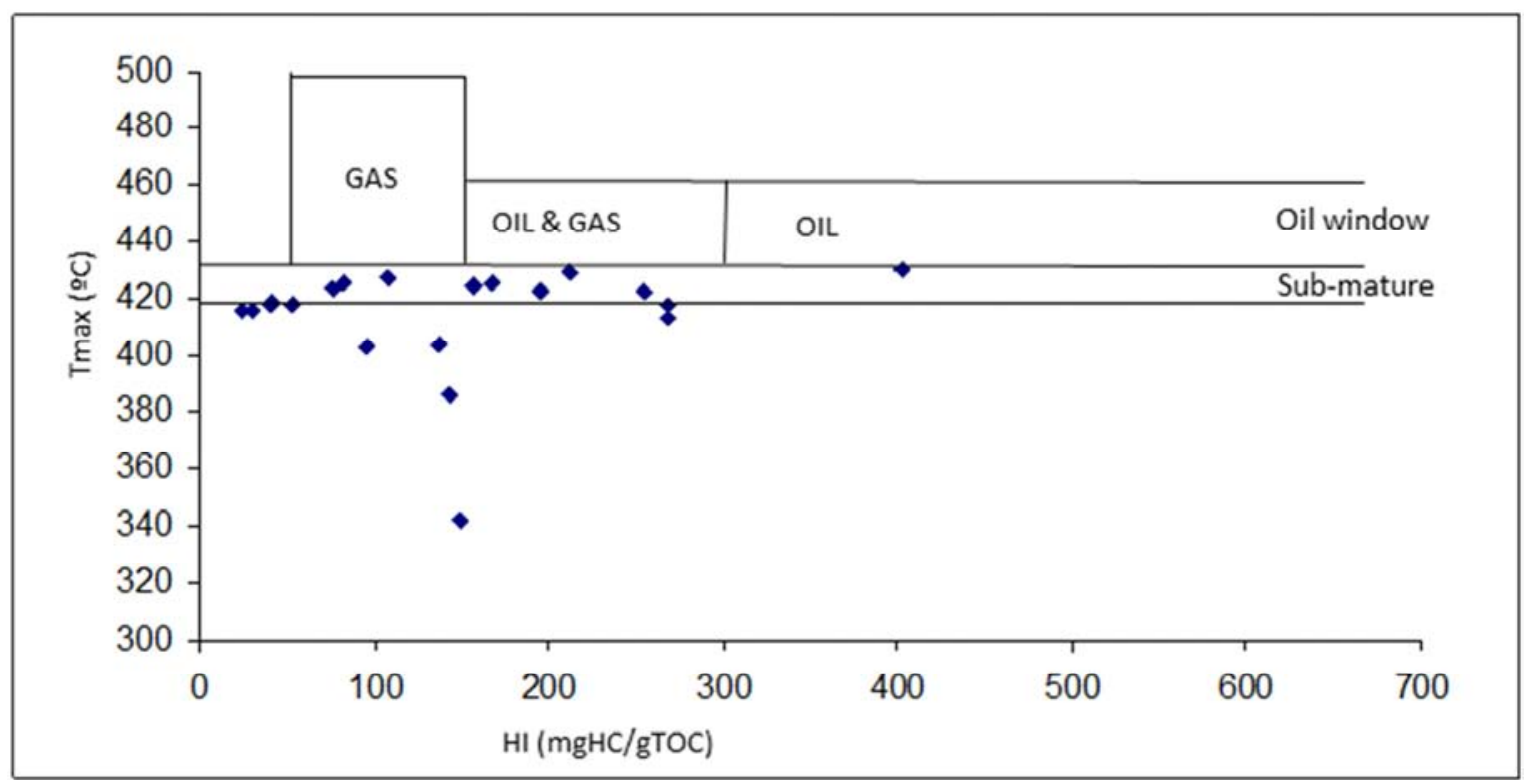

Figure 16. HI-Tmax plot of samples from the Bida Basin showing that source rocks are generallysub-mature to marginally mature. Note: Samples are from outcrops and shallow subsurface. At greater depths source rocks may have entered the oil window.

\section{Potential Petroleum System}

The source rocks in the Bida Basin comprise the dark carbonaceous shales of the Kudu Shale Member within the Enagi Formation and the Ahoko Shale Member within the Patti Formation. The Bida/Lokoja Formation sandstones as well as the well sorted sandstones in the Enagi Formation constitute potential reservoirs in the basin. Regional seals are provided by the clayey members of the Enagi and Batati Formations. Potential traps are both structural and stratigraphical. 


\section{New Insights}

Detailed field mappings carried out by [5], [6], [9] have not identified the Batati Formation at the previously assigned Type Locality at Batati village in the Northern Bida Basin. The Batati Formation which is supposed to be of Maastrichtian age and of clayey-ironstone lithology is nowhere mappable at Batati village or anywhere near it. What can be assigned to the Batati Formation are the ellipsoidal ironstones embedded in clays and claystones on top of the Enagi Formation, mappable at Pattishabakolo (PSK) village near Bida (Figure 8) and at Kandi village on the Lapai-Gulu-Gegu road. This formation should be redefined as PSK Formation or Kandi Formation after careful strato-lithological loggings. In the Southern Bida Basin, the Patti Formation is also not mappable at the previously assigned Type Locality of the Mount Patti in Lokoja but mappable at Gegu, Ahoko and midway on the Agbaja Plateau (Figure 9). This formation should be redesignated as PattiAhoko Formation with the Ahoko quarry on the LokojaAbuja expressway designated as the new Type Locality after careful strato-lithological loggings. Unconfirmed sources suggest sediment thickness in the Bida Basin may be up to $7,000 \mathrm{~m}$. Oil seeps have been recorded at Daban (Z. Faruq, personal communication), Muregi, Gabas, and Ahoko on the surface and/or in water wells.

\section{Conclusions}

The Bida Basin is one of Nigeria's inland frontier basins. The origin of these basins is related to the opening of the South Atlantic and the accompanying rifting in many areas of Western and Central Africa. Basinal fills comprise Campanian-Maastrichtian continental and marginal marine sediments. Source rocks of Campanian-Maastrichtian age run in a linear belt from the Anambra Basin in the southeast through the Bida Basin in the central region into the Sokoto Basin in the northwest of Nigeria. Potential petroleum systems exist in the Bida Basin. However, geochemical results obtained on surface and near surface samples from the basin show that organic matter in the source rocks are immature to sub-mature but may have attained the appropriate maturity at deeper depths to generate mainly gas and some oil. Some earlier identified litho-stratigraphic units in the Bida Basin have not been identified in this study at the Type Localities assigned by the earlier studies hence new stratigraphic nomenclatures and new Type Localities have been here-in proposed. This study has come up with an updated geology of the Bida Basin in Central Nigeria.

\section{Acknowledgements}

The Nigerian National Petroleum Corporation, the Ibrahim Badamasi Babangida University Lapai and the Niger State
Government supported this work at different stages.

\section{References}

[1] Ojo, S. B. 1984. Middle Niger Basin revisited: magnetic constraints on gravity interpretations. Abstract, $20^{\text {th }}$ Conference of the Nigeria Mining and Geosciences Society, Nsukka, pp 52-53.

[2] Ojo, S. B. and Ajakaiye, D. E. 1989. Preliminary interpretation of gravity measurements in the Mid-Niger Basin area, Nigeria. In: Kogbe, C. A. (Ed.), Geology of Nigeria, $2^{\text {nd }}$ edition, Elizabethan Publishers, Lagos, pp 347-358.

[3] Mohamed, A. Y., Pearson, M. J., Ashcroft, W. A., Illiffe J. E. and Whiteman, A. J. 1999. Modeling petroleum generation in the Southern Muglad rift basin, Sudan. AAPG Bulletin 83, 1943-1964.

[4] Obaje, N. G., Wehner, H., Scheeder, G., Abubakar, M. B. and Jauro, A. 2004. Hydrocarbon prospectivity of Nigeria's inland basins: from the viewpoint of organic geochemistry and organic petrology. AAPG Bulletin 87, 325-353.

[5] Obaje, N. G., Balogu, D. O., Yakubu, M., Idris-Nda, A., Goro, I. A., Ibrahim, S. I., Musa, K. M., Dantata, H., Yusuf, I., DadiMamud, N. J. and Kolo, I. A. 2013. Preliminary integrated hydrocarbon prospectivity evaluation of the Bida Basin in North Central Nigeria. Petroleum Technology Development Journal 3 (2), 41-71.

[6] Obaje, N. G., Idris-Nda, A., Okoro, A. U., Akpunonu, E. O., Jatau, S. B., Goro, I. A. and Dantata, S. H. 2015. G\&G assessment of hydrocarbon new business opportunities in the Bida Basin of Central Nigeria. Oil and Gas Journal (USA), April 6, 2015 edition.

[7] Ladipo, K. O., Akande S. O. and Mucke, A. 1994. Genesis of ironstones from the Mid-Niger sedimentary basin: evidence from sedimentological, ore microscopic and geochemical studies. Journal of Mining and Geology 30, 161-168.

[8] Akande, S. O, Ojo, O. J., Erdtmann, B. D. and Hetenyi, M. 2005. Paleoenvironments, organic petrology and Rock-Eval studies on source rock facies of the Lower Maastrichtian Patti Formation, southern Bida Basin, Nigeria. Journal of African Earth Sciences 41, 394-406.

[9] Rahaman, M. A. O., Fadiya, S. L., Adekola, S. A., Coker, S. J., Bale, R. B., Olawoki, A. O., Omada, J. I., Obaje, N. G., Akinsanpe, O. T., Ojo, G. A., Akande, W. G. 2018. A revised stratigraphy of the Bida Basin, Nigeria. Journal of African Earth Sciences 70, 23-35.

[10] Adeleye, D. R. 1975. Nigerian Late Cretaceous stratigraphy and paleogeography. AAPG Bulletin 59, 2302-2313.

[11] Braide, S. P. 1992b. Syntectonic fluvial sedimentation in the central Bida Basin. Journal of Mining and Geology 28, 55-64.

[12] Udensi, E. E. and Osazuwa, I. B. 2004. Spectral determination of depths to magnetic rocks under the Nupe Basin, Nigeria. Nigerian Association of Petroleum Explorationists (NAPE) Bulletin 17, 22-27. 